\title{
an exercise
}

\section{in anti-imperialism: the thirties}

judith papachristou

Critics of Franklin D. Roosevelt's foreign policy during the 1930's are familiar to students of United States domestic and foreign politics; in newspapers, periodicals, on radio and on the floor of Congress, the critics' vociferous opposition to the actions and inactions of the administration won them a place in American history. In general, historians have tended to label most of these critics as "isolationists"; more recently, they have been viewed in the larger context of pacifism and an American peace movement. ${ }^{1}$

I think that there were ideas and attitudes in much of the criticism of Roosevelt's policy that were essentially neither isolationist nor pacifist in character, ${ }^{2}$ and that these ideas and attitudes comprise an important strain of American thought that has been overlooked and distorted by mislabeling. Many were common not only to pacifists and isolationists but also to more conventional liberal and conservative thinkers; I classify their common theme as "anti-imperialist."3

American isolationism was primarily concerned with the nation's loss of unilateralism. The significant forces pulling the nation toward war were seen as external to the United States, and isolationist spokesmen often were afflicted with robust nationalism and sometimes with racism. The isolationist spokesmen of the thirties tended to be more concerned with Europe than with the Pacific, where war with Japan was considered less dangerous than one in Europe. ${ }^{4}$ Pacifists were, by definition, opposed to involvement in any war.

In contrast, the anti-imperialism of the 1930's focused upon American policy, rather than that of other nations, as the force propelling the country toward war. Both moralistic and pragmatic, anti-imperialist thinking was critical of American motives, methods and goals; it was not 
opposed to internationalism per se. Anti-imperialists were primarily concerned with the impending conflict between the United States and Japan rather than with European affairs, although the latter were not ignored. Although some anti-imperialist spokesmen were also pacifists, many were not.

I am going to assume that anti-imperialist ideas are significantly different from those of isolationism and pacifism where they have been carelessly grouped. I will try to isolate the anti-imperialist strain of thought, to examine its content and viewpoint and to identify its spokesmen; and finally to consider the failure of anti-imperialism to influence the mainstream of American thinking, as well as its place in the American tradition.

By and large, most of the books, magazine articles and speeches that exemplified the anti-imperialism of the thirties were produced between the summer of 1937 and the spring of 1938. There was earlier antiimperialist literature in 1934 and 1935, but the outbreak of the SinoJapanese war in 1937, the strenuous efforts by peace groups to pressure the administration to apply the neutrality laws to that war, the Panay crisis in December 1937 and government proposals for extensive naval building combined to produce a period of peak activity. After 1938, anti-war, anti-imperialist agitation diminished steadily in the face of growing public hostility to Japan and increasing newspaper and political support for administration policy. Like isolationism, it abated rapidly. By 1940, the Tripartite Pact linked Japan and Nazi Germany tightly together in American minds, and the anti-imperialist movement was all but dead. Here and there an isolated voice questioned American policy, but it made no echoes and received no answers.5 "The American mind," wrote historian Tyler Dennett at that time, "is now nearly if not quite closed to argument on behalf of Japan." 6

Anti-imperialist spokesmen in the thirties were not organized in any way nor were their efforts coordinated. Politically and economically, they were a heterogeneous group; yet on the subject of American relations with Japan, they held a common set of ideas. They believed that United States policy under Roosevelt was leading the nation toward war. They did not believe that war with Japan was inevitable nor did they view such a war as potentially advantageous for the United States. They called not for isolation, but for an end to a particular kind of involvement in East Asia which, in their view, was bringing the country to the edge of conflict, although their differences prevented any agreement on precisely what policies should be taken to avoid war.

A fundamental assumption among administration critics was that economic motives were the foundation of the country's policy in the Pacific. The Open Door, the traditional American policy toward China, was regarded as nothing more than a means of upholding the rights of American business in China, and present policy was seen as likely to 
"turn out to be little more than the old imperialism with a new name." 7 More specifically, the anti-imperialists assumed that Roosevelt was committed to the protection and extension of American business interests in East Asia and was willing to risk war in order to do so. Conservative critics of the President, such as Nicholas Roosevelt, an ex-governor of the Philippines, who felt forced to confess that American interests in the Pacific were selfish were reinforced by less restrained critics such as U.S. Representative Robert G. Allen of Pennsylvania who proposed that the United States was arming to make the Orient "safe for the Standard Oil Company."8

Roosevelt's requests for a large and growing navy and his refusal to withdraw American troops from China (the 13th Regiment was stationed at Tientsin and American gunboats regularly patrolled the Yangtze River) were viewed as dangerously provocative. In hearings held by House and Senate Committees on Naval Affairs on proposed naval appropriations in the spring of 1938, administration naval policy was repeatedly described as offensive in intent and effect, rather than defensive. And behind this policy, it was said, lay the determination to protect and advance private investments and trade interests abroad. "We must not fight," stated the Ohio Valley Labor News, "to save the investments of corporations which hold immense concessions in China, protected at the present time, by American gunboats."' As early as 1935, and again at the time of the legislative hearings, the editors of The Nation expressed fear that United States naval strategy against Japan appeared offensive, not defensive. Commenting on the absence of appropriations for coastal defense, the editors questioned the true intent of the White House appropriation bills. ${ }^{10}$

Anti-imperialist critics called for clarification and exposure of American policy in the Far East. They believed the public was generally unaware of the provocative nature of the country's foreign policy and portrayed a nation tricked into war for the benefit of the few who had investments and commercial interests in East Asia.11 "They are educating you [the American people] for war," warned Senator Rush D. Holt on a national radio network, ". . . shall your brother be shot to protect the oil business in China?"'12 Similarly, in protesting the use of American troops and ships to protect business interests in China, the Executive Committee of the National Council of Methodist Youth accused the president of whipping up public sentiment against Japan. "If you lead us into war in the Far East," the council warned, "we will not support your Administration in that war. It will not be our war, we cannot fight in it."13

Much emphasis was given to the argument that private U.S. investments and commercial interests in the Pacific were not large enough to justify a costly war. From this point of view, the President was not only leading the country toward war but also toward a war with rela- 
tively low stakes. Again and again, spokesmen of different persuasions cited the disparity between the returns and benefits from American economic activity in Asia and the high cost in money and lives of Roosevelt's policy of protecting these interests. The total value of United States investments in China was equated with the cost of four new battleships and was shown to total less than the increase proposed in the controversial naval legislation before the Congress. ${ }^{14}$ A study by the Institute of Pacific Relations in 1936 revealed that American trade with the Far East was relatively small, totalling some $\$ 837$ million, that most of it was with Japan, and that, in the balance, the United States imported more than it exported to East Asia. American investments in the Far East, adding up to some $\$ 750$ million, comprised between 5 and 6 percent of the nation's total foreign investment. Tallying up the annual costs of the Departments of State, Commerce and Agriculture concerned with the Far East, author Miriam S. Farley concluded that the country spent at least $\$ 339,570,000$ in the Far East to protect an annual profit of $\$ 128,000,000$. If the naval costs of protecting trade were included, Farley noted, the United States spent seven times what it received from business activities in the Far East. ${ }^{15}$ In more dramatic terms, newspapermen Boake Carter and Thomas Healy revealed that the total direct American investment in the Far East was the equivalent of one half the amount spent in the country for cigarettes in 1937 and one sixth the amount spent for liquor. Adding to direct American investments in the Far East the amount of indirect investments, such as banks and missionary property, Carter and Healy reached a total of $\$ 750$ million, oneseventh of American investments in Latin America. In China specifically, American investment was one-twentieth the total liquor outlay of the country, a direct investment of $\$ 132$ million. Turning to trade, Carter and Healy echoed Farley, pointing out that Japan was the country's third best customer in the world while China was the fifteenth. ${ }^{16}$

The panic caused by the Panay incident in December 1937 when Japanese planes bombed and sunk a marked U.S. gunboat in a daylight attack on the Yangtze River intensified criticism of Roosevelt's policy of protecting these relatively small investments. Even before the episode focused attention on the fact that American naval gunboats regularly patrolled the Yangtze River and protected Standard Oil ships in Chinese waters, Standard Oil had been singled out as one of the major investors in the Far East, holding perhaps one third the total American investment in East Asia. Also cited as major investors were the Electric Bond and Share Co., the National City Bank of New York, Pan American Airways, International Telephone and Telegraph, and Socony Vacuum Oil Co. ${ }^{17}$ After the Panay sinking and the waves of emotion that flooded the country following the episode, anti-imperialists bemoaned the dangers inherent in Roosevelt's China policy. ${ }^{18}$ 
Having proposed that the President was moving the country toward war in order to protect private economic interests and having shown that those interests were small and not very profitable to the country at large, critics attempted to explain the apparent folly of the administration's willingness to risk war over such small stakes. To some, it seemed that Roosevelt was preparing to fight not only for the protection of the small American investment (some $\$ 750$ million) but also for the immense interests of Great Britain (estimated at approximately $\$ 4$ billion). ${ }^{19}$ This was one more example, noted the anti-imperialists, in which the American people were being misled about the nature of the country's Far Eastern policy. ${ }^{20}$ Isolationists too, when they turned to the Pacific, saw the United States being tricked into conflict with Japan for the protection of British interests, but they paid little attention to the role of American imperialism. ${ }^{21}$

In addition to arguing that American economic interests in the Far East did not justify a war, anti-imperialists also proposed that such a war was unnecessary, that the United States could ignore what Japan did in East Asia, and that Japanese control of China, Manchuria and even the Philippines, would not be harmful to the interests of the United States. The Sino-Japanese conflict did not in itself threaten world peace..$^{22}$ Japanese control of East Asia would deprive the United States of only one raw material, and that was tin, which could be stockpiled. The American stake in the Far East did not justify even a fifth class war, argued Healy in front of the Senate naval committee. "Not the slightest evidence has been brought forth to prove that Japanese control of all or part of China will be a real menace to the lives or property of Americans that are in China." American sales in Manchuria had actually increased, rather than decreased, since Japanese control was extended over the area. ${ }^{23}$

Representative Henry Lucky showed members of the House Naval Affairs Committee a letter from Theodore Roosevelt to William Howard Taft in which the ex-President wrote that the United States could keep Japan out of Manchuria and Korea only by war and that American interests there were not really important enough to warrant such a war. At the present, anti-imperialists argued, Japan was more of a threat to Soviet interests in northern China than to American. Repeatedly, they pointed out the anti-Japanese position of the Communist Party in the United States and its call for a boycott against Japan, which confirmed their contention that Japan threatened Russia in the Far East. ${ }^{24}$

Few anti-imperialists were as extreme as isolationist Ralph Townsend who proposed that Japanese intervention in China was a positive blessing for the Chinese who wanted only the "privilege of working, eating, gossiping, and dying in peace," which the Japanese could guarantee to them but which the Chinese were unable to get for themselves. ${ }^{25}$ However, many critics argued that Japan was only following in the footsteps 
of the Western powers in China. They proposed that Japan had legitimate grievances to justify her aggressions in north China, which were in the tradition of Western imperialism. "This country [the United States] is no country to be telling Japan to get out of China, until our investments and imperialistic interests there have been removed," declared the representative of the National Council of Methodist Youth to the House Naval Committee. ${ }^{26}$ Over and over, the Roosevelt policy was decried as one of selfish imperialism whereby the United States, along with Britain, France and Russia, attempted to hold onto its large share of the world's resources and wealth, and to prevent the "have nots" of the world, Japan and Germany, from sharing in them. Frederick J. Libby, a Quaker pacifist and executive secretary of the National Council for the Prevention of War, pointed out that the peace-loving nations of the world had four-fifths of its resources and were, therefore, peace-loving. Those who wanted to change the situation were, Libby said, labeled "aggressive." Only when the world's resources were equally divided, he predicted, would there be peace. ${ }^{27}$ Retired Major General Smedley D. Butler, who described his career as "running around the world guarding Standard Oil tins ....," presented members of the Senate Committee on Naval Affairs with a personal confession and condemnation: "I have been on fourteen expeditions robbing little Central and South American countries in the interests of Wall Street and their bankers."2s United States action in Vera Cruz, commented Maine Republican Congressman Ralph O. Brewster, was comparable to that of the Japanese in China. ${ }^{29}$ The United States "has no more right to run South America than Japan has to rape China," said Benjamin Marsh. ${ }^{30}$

Speaking in a more pragmatic vein, Tyler Dennett proposed that war between the United States and Japan would accomplish nothing except to leave the United States "holding a bag." China, he predicted, would bring troubles: unless the United States was prepared to keep troops there, communism would sweep over Asia. The fruits of war would be rotten ones. ${ }^{31}$ Similarly, Norman Thomas, Socialist Party leader, offered a pragmatic argument: if Japan defeated China, he predicted, she would be bogged down in guerrilla war and resistance; if the United States defeated Japan, we would have to remain in China, would have to become a militarized nation, and would become a fascist state at home and the arch-imperialist of the world. ${ }^{32}$

Numerous and various critics offered warnings that the U.S. was heading for a war that was unnecessary and unwise. To many of them, who saw danger and folly in Roosevelt's policy, the solution seemed apparent, and between 1934 and 1938 most anti-imperialists called for withdrawal from the Far East and renunciation of the self-imposed commitment to defend China and the Philippines. Bruce Bliven, New Republic editor, expressed the most common sentiments of the antiimperialists. "We could buy out our entire interest in the Orient, in- 
cluding Japan, China and the Philippines, for less than what this country spends every year on barbers, hairdressers, and manicurists." 33 Pull out, buy out, and give up the capitalist dream of profit from the development of East Asia, was the popular solution. For the socialists, such a pullout was intricately tied with radical change in the economic system. For the pacifists, it was necessary to avoid war. For more traditional thinkers in the anti-imperialist camp, withdrawal was a problem, a chimerical goal, and they generally settled for less. The Nation, for example, deploring the goals of the United States in East Asia, argued for collective security, a cooperative Anglo-American effort to maintain the status quo without the use of force or threat of force. Withdrawal, the magazine maintained, would only strengthen Japan..$^{34}$

Surveying the sources of anti-imperialist attitudes and ideas during this period, we see that the ranks included persons of disparate ideological commitment: although pacifists and socialists predominated, persons of liberal and conservative bent, basically content with the existing economic and political system of the country, Democrats and Republicans, internationalists as well as nationalists, contributed to the antiimperialist theme during these uncertain years. Among the most vocal and persistent were the pacifists.

As Charles Chatfield points out in his recent study of American pacifism from 1914 to 1941, pacifists had a long tradition of opposition to economic imperialism, speaking out against government policy in the Philippines and in Latin America in the 1920's. Throughout the twenties, the pacifist journal World Tomorrow decried the imperialist competition between the United States and Japan and expressed fear of its coming to a violent conclusion. ${ }^{35}$ Similarly, in the thirties a large and influential segment of American pacifists went beyond opposition to conflict with Japan on moral grounds. They attempted to analyze the world situation, the policies of the administration, and to seek the causes of the war they feared was evolving. In World Tomorrow and Peace Action, in regular news releases, radio broadcasts and in appearances before Congressional committees and public meetings, they not only brought their moral views before the country, but often expressed an anti-imperialist interpretation of events.

Frederick Libby, for example, was an indefatigable spokesman. Persistently, he used the forum of Madison Square Garden or a Congressional hearing room to condemn war as unethical and to bring his antiimperialist analysis of current events to the public. Also prominent was Kirby Page, counted in both pacifist and socialist ranks, who went beyond his fervent belief that "war is an utter denial of the spirit and example of Jesus" to analyze the world situation. The threatening war was, he proposed, the result of capitalist competition, and Japan, Germany and Italy, deprived of their share of the resources of the world by the U.S., Britain and France, would fight to get their way. ${ }^{36}$ 
Bruce Bliven was both pacifist and socialist in his views. Assuming that imperialism was an inevitable product of capitalism, the socialists had no doubt that American policy was imperialistic. Frequently, they pointed to the lack of idealism in American foreign policy and added to the weight of anti-imperialist thinking in the country. But the Socialist Party was not in the forefront of the anti-imperialist movement for several reasons. At this time, the party was torn by serious factional strife; individual socialists were also in conflict as their pacifist tendencies met head-on with their opposition to fascism. Norman Thomas was more concerned with Europe than with Asia and became a major opponent of collective security and aid to the Allies. In addition, the socialists believed that peace would be secured not through changing the foreign policies of nations but only after popular efforts had brought about a new social and international order. Change of existing societies was their principal goal.

The sources of anti-imperialist ideas include many persons and organizations that do not fit neatly into categories such as pacifist and socialist. Men such as Walter Van Kirk, Methodist leader and active peace worker; Clark Eichelberger, director of the League of Nations Association; Philip Jessup, professor of international law at Columbia University; Thomas H. Healy, Dean of the School of Foreign Service at Georgetown University; historian Charles A. Beard and journalists such as Boake Carter and Nathaniel Peffer can be labeled as liberal thinkers. Similarly, church groups such as the National Council of Methodist Youth, the Executive Committee of the Mennonite Peace Society, the Commission on World Peace of the Methodist Episcopal Church; lay organizations such as the Carnegie Endowment for Peace and the League of Women Voters; and publications such as the Nation, the New Republic and Asia, were sources of anti-imperialist ideas. These liberals, themselves a highly heterogeneous group, and the pacifists noted above comprise the largest number of anti-imperialist spokesmen, although others, such as Representative Hamilton Fish and Nicholas Roosevelt, should not be overlooked.

No single anti-imperialist statement is better known than the words of Charles A. Beard to the House Naval Affairs Committee in which he declared: "From long travel and study in the Orient, I have come to the conclusion and I will say it here as emphatically as I can, that the whole of the Orient from Siberia to Singapore is not worth the bones of one American doughboy today. Stay out of it."37 Closely tied to the populist reform tradition of the early part of the century and to the socialist tradition, Beard was a prolific critic of administration policies during the thirties. He is not, however, one of the most frequent sources of anti-imperialist writing. When considering American foreign policy, he emphasized that it would lead to international involvement that would distract the nation from urgent domestic reforms. "If there is 
anything in American traditions and practices to guide us, it is that a wider spread of economic calamity will culminate in a foreign war, rather than in a drastic reorganization of domestic economy."'38 Beard's fear that war would prevent reform was not unusual. Benjamin Marsh, for example, speaking for the People's Lobby, said that measures to abate the Depression had failed and that war in Europe and the Far East was being used to distract the people from this failure. ${ }^{39}$ Libby and other spokesmen for the National Council for the Prevention of War reiterated this idea, as did Thomas and other socialists. ${ }^{40}$

Beard's chief concern was the domestic scene, and he consistently related international events to the internal situation. Indeed, he saw the very origins of modern American imperialism, the imperialism of Mahan, Theodore Roosevelt, Lodge and Beveridge, in a concerted effort to divert the country from the "specter of Bryanism."41 According to Beard, the very validity claimed for imperialism-surplus production and the need for markets-was rooted in the failure of the economic system to give its own members sufficient purchasing power. If the American economy were reorganized and purchasing power were increased, the nation would be free from surplus and from the fear of surplus production; it would no longer be necessary to seek overseas markets and concessions or to sell abroad. ${ }^{42}$

Thus, Beard believed that Franklin Roosevelt was moving toward intervention and toward cooperation with Britain and France to divert the nation from its troubles. He also recognized diverse and selfish pressures on the president: those of the munitions and naval supply manufacturers, the cotton growers, the railroads, the banks, and the exporters and importers who hoped to profit from American involvement. ${ }^{43} \mathrm{He}$ insisted that America's problems would not be solved overseas. Foreign trade and foreign affairs affected the economy only minimally. Espousing a version of economic isolationism that he called continentalism, Beard proposed that foreign trade was generally dangerous, that it provoked rivalries and trouble, and that the nation should import only what was necessary to maintain its standard of living. ${ }^{44}$ "Nothing we can do for Asiatics," he argued, "will materially increase our trade or add to our, or their, well being." 45 Only on occasion did Beard turn his attention to the nature of contemporary American power and criticize the development of a navy for the protection of "acquisitive private interests." 46 No gain would come from international greatness, he warned, and cautioned against the United States following in the dangerous paths of the Roman and British empires. ${ }^{47}$

The best example of the liberal viewpoint can be found in Nathaniel Peffer's writings, which were of considerable scope and influence during the decade. Peffer was, in the late thirties, one of the most frequent and prominent contributors to periodicals on Far Eastern issues. As a journalist, Peffer had spent many years in the Orient, first going in 1915 as 
a reporter to Shanghai and then to Peking where he was the New York Tribune correspondent. Years of residence in China qualified him to lecture at Columbia University in the early thirties. In 1936, he returned to the Far East for two years. Throughout the thirties, and up to the outbreak of the war, he was a regular magazine contributor. ${ }^{48}$

American policy in the Far East, in Peffer's view, had long been selfserving. Since 1900, the United States had "unswervingly opposed the effort of any power to conquer, dominate, or control China or take a lien on its opportunities for development." Americans were determined that "China shall remain a free field for American economic enterprise." This policy, he wrote, was based on the assumption that the wealth and power of the nation depended upon the pursuit of an imperialist course in the undeveloped parts of the world. ${ }^{49}$

Although United States trade and investment in China were relatively small, and the net return from the Far East was negative, Peffer observed that some segments of the country profited from economic activity in Asia even though the average person did not. Those who did profit, and would be affected by cessation of Far Eastern trade and the loss of capital, represented important corporate interests. In view of the depression, even small losses, especially in trade, were undesirable. He concluded that "the Western Powers cannot permit Japan to take possession of the Far East without accepting the risk of national insolvency." 50

That Japan threatened to master East Asia was apparent to him. In 1935, he pointed out the comparative growth of Japanese textile trade; exports to India had increased by $90 \%$ in two years; in 1933, Japan sold more cotton and rayon cloth to India than did Britain. Her exports to the Dutch East Indies were larger than the Netherlands'. Exports to Kenya and Uganda were six times Britain's. The increase in Japanese sales to Latin America was growing markedly. ${ }^{51}$ Japan, while the West was preoccupied with European affairs, was out to take advantage of her golden opportunity. "In plain words," Peffer wrote, "unless there is war, Japan will rule all Eastern Asia" and the United States and Europe will be excluded from the market of one quarter of the population of the earth. "America must forswear its future in the Far East or overcome Japan. America must yield or Japan must yield. . . . Japan will not." 52

Thus Peffer concluded that the United States could either withdraw from the Far East and renounce America's economic future there or face war with Japan. He examined these alternatives throughout the decade. Considering withdrawal, Peffer questioned the value of the trade and investment that tied the nation to East Asia. He balanced the small yield from involvements in the Pacific against the cost of armaments there, and he noted that the United States did most of its trade (in the twenties, $75 \%$ ) with non-colonial nations, i.e., with developed economies. ${ }^{53}$ In another context, he observed that imperialist "possession" 
of an area did not necessarily guarantee trade, for example, in India, where Japanese trade flourished. Looking ahead, Peffer predicted that all imperialism in China would eventually fail as China developed. The gains of imperialism, Japanese or American, would diminish. "All empire carries within itself the seeds of its destruction." ${ }^{4}$

Peffer expressed a preference for withdrawal and a conviction that war was not a solution for international problems. ${ }^{55}$ However, he concluded that the United States could not renounce its economic role in East Asia and give up its traditional China policy, despite the danger of war. The China policy was tied to the basic character of the country as an independent capitalist society seeking material progress and growth. Renouncing imperialism presupposed basic changes in the structure of society and in social philosophy. Not only would it bring a loss of power to established economic forces, but it would also necessitate reorganization of the economy to permit independence from overseas markets. Only by socialization and redistribution of wealth, Peffer concluded, could the United States absorb what it could produce and eliminate war. Despite the demonstrable evils of imperialism, its inevitable self-defeat and the looming war, Peffer predicted that day-to-day profits would keep the country moving along the road it had chosen. War was inevitable..$^{56}$

Gradually Peffer came to accept the war, as did many other antiimperialists. By 1939, his writings supported a strong United States stand against Japan. In Harper's in March, 1939, noting once more the irrationality of the conflict with Japan, he advocated the use of force as a deterrent to Japanese advances in East Asia and as a way to avoid war. "One of the surest safeguards against any extended adventurings by the Japanese in the next few years is an American navy capable of striking swiftly and decisively from its own waters. ... [I]n the present state of international society the absence of force is far more likely to [precipitate the necessity of its use], and to do so under conditions of desperate disadvantage to those who are without force." It had, in his view, become necessary to arm to prevent Japan from doing the things that would force the United States to go to war against her. ${ }^{57}$

Peffer also advocated economic pressures against Japan to prevent her conquest of China. He urged the use of economic penalties, an embargo if necessary, and argued against renewal of the Japanese commercial treaty. Thus, Peffer had come around to the policies of the Roosevelt administration, hoping they might postpone the conflict with Japan until war in Europe was over, and the United States, Britain and France could set terms for the Far East. 58

Eventually, Peffer asserted, the "Prerequisites to Peace in the Far East" entailed voluntary abandonment of the territorial, political and economic positions of the West in China. Japan must be taught a lesson, but must also be able to live in the post-war world. The West must recognize her natural market in China and offer Japan solutions to her 
real economic problems. Looking to the future in the Pacific, Peffer believed that peace was possible only if imperialism ended. China must be independent; self-government and independence must come to Southeast Asia too. The West must uproot the imperialism of the past if there were to be no more Pacific wars. ${ }^{59}$

The development of Peffer's ideas offers a clear example of the course of liberal thinking that moved from advocacy of withdrawal in East Asia to support of Roosevelt's policy and eventually to support of war with Japan. The path Peffer took was trod by other anti-imperialists who eventually supported war preparedness and the war itself. The New Republic in its editorial views offers a similar example, consistently advocating withdrawal until the fall of 1939 when it supported aid to the Allies and changed its posture.

In the thirties, the arguments of anti-imperialism, like those of pacifism and the various persuasions of isolationism, were part of an extensive public debate over the role and direction of the nation in international affairs. Like the other points of view, anti-imperialism was overwhelmingly rejected by the Roosevelt administration and by the American public which chose to accept the view that conflict with Japan was part of a larger conflict that threatened the well-being of the Atlantic community and therefore of the United States. By 1940, Roosevelt's policies of aid to the Allies were victorious.

This triumph was a profound event in American history, and the forces that led to Roosevelt's success and the defeat of isolationism and other alternatives have been studied and interpreted extensively. They are, of course, beyond the scope of this paper. But there appear to be factors in American anti-imperialism itself that contributed to its failure to influence public opinion and the direction of policy in the thirties, and these factors are of special interest to us.

Most important, the anti-imperialism of the thirties was not a movement but a set of ideas and attitudes. Though lack of organization and cohesion seriously weakened the cause, they cannot explain the failure of the ideas to spread. The failure lies in the ideas themselves, for American anti-imperialism in the thirties was not willing or able to come to grips with the logic of its own position. The realization that American foreign policy was intricately and inextricably tied to the basic institutions of the country was one of the important ideas of antiimperialism, but it was also one of its greatest problems. For the antiimperialism of the thirties, like earlier movements in the United States, was neither Marxist nor revolutionary in inspiration, composition or ideology. ${ }^{60}$ It was a spontaneous native effort that generally did not spring from or rest upon any single notion as sturdy as the Marxist's view of society. American anti-imperialism in the thirties was undeveloped, eclectic and undoctrinaire. Its well-springs often were a com- 
bination of a sense of justice and a practical concern for the future. Although most of the anti-imperialist spokesmen saw the major causes of the coming confrontation with Japan in the country's economic and political institutions, by and large, they were not prepared to work actively for radical change in these institutions. Those who were did so without much hope of accomplishment. The failure of American socialism at the polls and the growing disenchantment of the left with the Soviet experiment gave a rather half-hearted character to left-wing movements for radical change. The impossibility of changing the direction of U.S. foreign policy by first changing the society that generated such policies was clear. In effect, the anti-imperialists were advocating a foreign policy that could not be; their position, and most knew it, was wistful and chimerical.

Withdrawal from East Asia not only required radical change in American institutions and leaders, but also ran counter to the attachment of the public to the traditional American policy. The public had, after all, rarely opposed the "open door" in China or the growing hostility between the United States and Japan. Even if the basic premise of anti-imperialism was correct and the Roosevelt government had as its main goal the advancement and protection of U.S. economic interests in the Pacific, by the 1930's the American involvement in Asia meant something different from this to the public. Any effort to alter American policy would have had to cope not only with the policy makers but also with the policy approvers, the American public. One need only note the lack of opposition to war with Japan, once it came about, and contrast this to the opposition to the war in Viet Nam in the sixties and seventies, to realize that World War II was a "popular" war. In practice, the American commitment in the Pacific amounted to more than a commitment to protect trade and investments, and the anti-imperialist arguments did not begin to deal with the sentimental and psychological aspects of the commitment to the Far East.

Economic determinists, for example, might well have documented the vast financial investment of American churches in China, listing holdings in real estate, hospital and school buildings, and revealing what the churches had to lose from Japanese domination of China. But such an exposé of economic interests would not have wiped out the sentimental attachment to the American Christian mission that years of church ser. monizing and mission reporting had built up. Similarly, although administration critics could document the absence of any binding commitment by the United States to defend China against Japanese military advances, this in itself did not counteract the feeling of obligation and responsibility to China that had been nurtured in the American public by leaders such as Wilson and Roosevelt. The belief in an American mission in China, coupled with a natural sympathy for the underdog, the blatant brutality of Japan's imperialism and the association of Japan 
with Nazi Germany meant that a host of factors other than economic ones played a role in determining policy in the thirties.

Ever since Theodore Roosevelt had proclaimed the value to the United States of a balance of power in the Pacific, of preventing either Russian or Japanese domination in East Asia, such a balance had become identified with national security. The relationship between the balance of power in Asia and American security was more often referred to than analyzed. Japan clearly did not threaten the continental United States. Even in the early twenties, when anti-Japanese fear was widespread in the country and particularly in naval circles, the predicted war with Japan was expected to take place in the Far East. ${ }^{61}$ However, even if the anti-imperialists were correct and "national security in the Pacific" really was synonymous with freedom for American enterprise in Asia, by the thirties, Japanese domination of China was widely seen as a threat to American security in the Pacific.

Here again, the anti-imperialist viewpoint did not come to grips with the emotions and beliefs of the public; its rational approach and its collection of data could not counteract long-held attitudes and beliefs. Moreover, anti-imperialism, whatever its validity, placed the onus of responsibility for the threatening war on American policies as well as Japanese, and at times even excused Japanese aggression in light of the trespasses and injustices of the western powers in the past. Such selfcriticism soon was read as lack of patriotism.

Characteristics of anti-imperialism in the thirties were a rational style, undoctrinaire and eclectic; the avoidance of radicalism and its larger implications; a tendency to focus on the practical problems at hand; diverse and often incompatible supporters; pragmatism, flexibility and eventual compromise. Anti-imperialism had, in short, many characteristics of the liberal tradition and earlier reform traditions in the country. Like them, it had more to do with conscience than with guidance.

Anti-imperialism in the 1930's was a continuation of a long and generally ineffective tradition of opposition to the transition of the United States from a dependent colonial state to a dominant world power. Efforts to acquire Cuba, tied closely to sectional controversy over slavery, roused anti-expansionist sentiment. The purchase of Alaska occasioned intense debate. Criticism of administration policy in Santo Domingo after the Civil War was the beginning of consistent opposition to expansion of American interests in both the Pacific and South America, which climaxed in the anti-imperialist movement of 1898-1900. Robert Beisner's study of this movement offers interesting similarities and contrasts with the thirties. As Beisner notes, that movement was fairly well organized, contained prominent and prestigious figures, received considerable public attention and was basically a conservative movement, essentially isolationist and opposed to large changes in American 
life. The anti-imperialism of 1898-1900 was often racist in its arguments against involvement of the United States with non-Anglo Saxon peoples. Like the anti-imperialism of the thirties, Beisner's movement was diverse in membership and viewpoints; its arguments were both moralistic and practical although Beisner contends that the opponents of expansionism had not clearly thought out the consequences of their position. Despite its prominence, the movement failed.62 Anti-imperialism in 1898-1900 predated a costly war in the Philippines and decades of American imperialism in Central and South America. Similarly, the anti-imperialism of the thirties was followed by the very war it opposed, by the emergence of the United States as one of the dominant world powers in the Pacific and by two subsequent wars in East Asia.

At no time in American history has anti-imperialism been as vocal or as organized as in the decade of the 1960's. Although the opposition to the war in Indochina and calls for withdrawal from the Far East have some similarities to isolationist ideas, the movement of the sixties and seventies appears to fall squarely in the tradition of anti-imperialism and in many ways echoes the movement of the thirties. Against the background of this study, the contemporary movement seems to be a continuation and development of a lengthy tradition, a tradition that has been weak but persistent in our past, and a tradition whose full effects and importance are still to be evaluated.

\section{footnotes}

1. See for example, Selig Adler, The Isolationist Impulse: Its Twentieth Century Reaction (New York, 1957); Wayne Cole, America First: The Battle Against Intervention (Madison, 1953); Manfred Jonas, Isolationism in America, 1935-1941 (New York, 1966); and Charles Chatfield, For Peace and Justice: Pacifism in America, 1914-1941 (Knoxville, 1971).

2. The shortcomings of such labels are serious handicaps to a careful analysis of New Deal diplomacy, according to Lloyd Gardner, Economic Aspects of New Deal Diplomacy (Madison, 1964).

3. If what the author identifies as "anti-imperialism" had to be included in Jonas' scheme, where most administration critics are categorized as different kinds of isolationists, it would be closest to what he calls "radical isolationism." But it is the contention of this paper that such a classification is seriously misleading.

4. Jonas, 23-24. Cole, too, notes that almost all the attention of the America First organization, the active isolationist group he studies in detail, was given to European events. When, in 1941, the organization turned its attention to events in the Pacific, it was opposed to United States involvement there.

5. An example is Rush D. Holt, U.S. Senator from West Virginia, who, in a speech over national radio in October 1940, wondered, "Shall we be called upon to die for 'dear old Dong Dang' . . . ?” Holt's speech reprinted in Vital Speeches of the Day, VII (December, 1940), 153-155.

6. Tyler Dennett, “Japan's 'Monroe Doctrine' Appraised," Annals of the American Academy of Political Science (May, 1941), 62.

7. Tyler Dennett, “The Open Door," in Joseph Barnes, ed., Empire in the East (New York, 1934), 269-294; and Jonathan Mitchell, "Roosevelt's Far Eastern Policy," New Republic (September, 1937), 147-8.

8. Nicholas Roosevelt, "Japan's Challenge to American Policy," Asia, XXXV (February, 1935), 76-81. Allen, who spoke in January 1938 on a radio program sponsored by the National Council for the Prevention of War, is quoted in a press release by the council. The organization (referred to hereafter as the NCPW) was a clearing house for some twenty peace organizations. Its collected press releases and bulletins are referred to as Press Information. 
9. Hearings before the Committee on Naval Affairs, U.S. Senate, 75th Congress, 3rd Session, April 4-13, 1938, referred to hereafter as Senate Hearings; Hearings, U.S. Naval Affairs Committee (House), 75th Congress, Ist Session, referred to hereafter as House Hearings; and Ohio Valley Labor News editorial, September 3, 1937, quoted in NCPW Press Information, I.

10. The Nation (February 5, 1938), 141.

11. See, for example, the speech of Walter W. Van Kirk, spokesman for the National Peace Conference, representing 42 nation-wide organizations as diverse as the American Association of University Women, the NCPW, and the Carnegie Endowment, in Senate Hearings, 127-133.

12. Vital Speeches of the Day, December 15, 1940, 153-155.

13. NCPW, Press Information, 1938, II.

14. See testimony by Bruce Bliven, editor of the New Republic, House Hearings, 2146-2156.

15. Miriam S. Farley, America's Stake in the Far East (New York, 1936), 8-32.

16. Boake Carter and Thomas H. Healy, Why Meddle in the Orient? Facts, Figures, Fictions and Follies (New York, 1938), 173-190.

17. Ibid., 174, and The Nation, January 29, 1938, 117.

18. See, for example, The New York Times, December 12, 1937, 1.

19. Testimony by Boake Carter, House Hearings, 2402-2409; see also testimony by Frederick J. Libby, executive secretary NCPW, House Hearings, 2159-2184.

20. See, for example, Uncensored, February 3, 1940, 3. Although mainly concerned with European events, the weekly looked to the Far East to accuse Great Britain of tricking the United States into war by involving it in the Pacific first; also see editorial, Common Sense, VI (January, 1937), 3-4.

21. Cole's study of the America First organization gives an excellent example of this; see

House Hearings, 2276, for testimony by Hamilton Fish warning that Britain was using the United States to protect her billion-dollar investment in China.

22. Dennett, "The Open Door," 269-274.

23. Carter and Healy, 215.

24. House Hearings, 2157; Carter and Healy, 202-217; testimony by Major General W. A.

River, House Hearings, 2224-2236; and speech by Frederick Libby, Madison Square Garden, May 4, 1938, NCPW.

25. Ralph Townsend, Asia Answers (New York, 1936), 28.

26. House Hearings, 2245.

27. Speech at Madison Square Garden, May 4, 1938, printed in NCPW (IV).

28. Senate Hearings, 143.

29. House Hearings, 2234-2235.

30. House Hearings, 2410. Marsh was executive secretary of a peace organization, the People's Lobby. 470.

31. Tyler Dennett, "Why Bother About Japan?" Current History, XLIII (February, 1936),

32. Norman Thomas, "How Can We Escape War?" Nation (December 25, 1937), 707-709.

33. House Hearings, 2147.

34. See, for example, an editorial in The Nation (March 13, 1935), 292.

35. Chatfield, op. cit.

36. Kirby Page, Must We Go to War? (New York, 1937).

37. House Hearings, 2188.

38. Charles A. Beard, "National Politics and War," Scribner's, XCVII (February, 1935), 70.

39. House Hearings, 2410.

40. See NCPW, Press Information.

41. Beard, "Giddy Minds and Foreign Quarrels: An Estimate of American Foreign Policy," Harper's, CLXXIX (September, 1939), 337-340.

42. George R. Leighton, "Beard and Foreign Policy," in Howard K. Beale, ed., Charles A. Beard (Kentucky, 1954), 172-173.

43. Beard, American in Mid-Passage (New York, 1939).

44. Beard, "What Is This Sea Power?" Asia, XXXV (January, 1935), 4-9.

45. Beard, "Giddy Minds," 348.

46. Beard, "What Is This Sea Power?" 8-9.

47. Beard, "Giddy Minds," 350.

48. Nathaniel Peffer, "Peace or War," in Barnes, ed., Empire in the East, 314; "Too Late for World Peace," Harper's, CLXXIII (June, 1936), 32; "America's Choice in the Far East," Annals of the American Academy of Political Science (July, 1936), 89-93; and The Whitc Man's Dilemma: Climax of the Age of Imperialism (New York, 1927), 121.

49. Peffer, "Peace or War," 307 and $312-13$ in Barnes, ed., Empire in the East, and Must We Fight in Asia? (New York, 1935), 223.

50. Peffer, Must We Fight . . . ?, 135, and White Man's Dilemma, 298.

51. Peffer, Must We Fight ... ? 1-3, and 122-135.

52. Ibid., 122. 
53. Peffer, The White Man's Dilemma, 294-5.

54. Peffer, "The Fallacy of Conquest," in International Conciliation, a collection by the Carnegie Endowment for International Peace (New York, 1936), 117-212, and Must We Fight ... ?, 227.

55. Peffer, "America's Choice in the Far East," 89-93.

56. Peffer, Must We Fight ....?

57. Peffer, "In an Era of Unreason," Harper's, CLXXVIII (March, 1939), 343.

58. Peffer, Prerequisites to Peace in the Far East (New York, 1940), 62; "Our Job in the Far East," Harper's, CLXXX (April, 1940), 489-97; and "Positive American Action in the Far East," Annals of the American Academy of Political Science (July, 1940), 115-118.

59. Peffer, Prerequisites to Peace ... 64, and "Must There Be More Pacific Wars?" Reader's Digest, XLII (March, 1943).

60. See John W. Rollins, "The Anti-Imperialists and Twentieth Century American Foreign Policy," Studies on the Left, III (1962), 9-24. Rollins discusses the relation between American liberalism and imperialism and the efforts he discerns to reconcile the two. American Marxists were, of course, also anti-imperialists, but during this period it was Japanese imperialism in China that attracted most of their attention.

61. Gerald E. Wheeler, Prelude to Pearl Harbor: The United States Navy and the Far East, 1921-1931 (Columbia, Mo., 1963), xi-xii and 80-81.

62. Robert L. Beisner, Twelve against Empire: The Anti-Imperialists, 1898-1900 (New York, 1968). 